\title{
Bewacyzumab w leczeniu pierwszej linii u chorej na potrójnie negatywnego raka piersi w stadium rozsiewu — opis przypadku i przegląd literatury
}

\author{
Agnieszka Badora-Rybicka ${ }^{1}$, Beata Kaleta ${ }^{1}$, Łukasz Zarudzki², \\ Marlena Sikora-Jopek ${ }^{1}$, Elżbieta Nowara ${ }^{1}$
}

\begin{abstract}
Wprowadzenie. Angiogeneza i nadekspresja VEGF (Vascular Endothelial Growth Factor) odgrywają istotną rolę w rozwoju wielu typów nowotworów. Rola bewacyzumabu, humanizowanego przeciwciała anty-VEGF, w leczeniu chorych na rozsianego raka piersi pozostaje niejednoznaczna. Celem pracy jest przedstawienie przypadku chorej na potrójnie ujemnego, rozsianego raka piersi, która odniosła długotrwalą korzyść z immunochemioterapii jako pierwszej linii leczenia.

Opis przypadku. U 57-letniej chorej na raka przewodowego piersi prawej, po szerokim wycięciu guza i limfadenektomii pachowej prawostronnej (pT1NOM0) oraz uzupełniającej chemio- i radioterapii, po czterech latach od zakończenia leczenia rozpoznano rozsiew choroby do płuca lewego (dwie zmiany) i węzłów chłonnych śródpiersia. Chora została zakwalifikowana do immunochemioterapii — paklitaksel z bewacyzumabem. W wyniku leczenia uzyskano znamienne zmniejszenie wymiarów zmian przerzutowych. Nie obserwowano poważnych działań niepożądanych terapii, po zakończeniu leczenia paklitakselem kontynuowano podawanie bewacyzumabu w ramach leczenia podtrzymującego. Od października 2009 r. do września 2013 r. chora otrzymała 70 wlewów bewacyzumabu. We wrześniu 2013 r. leczenie zakończono z uwagi na progresję wielkości zmian w płucu lewym, nowych zmian przerzutowych nie obserwowano. Chora została zakwalifikowana do stereotaktycznej radioterapii.

Dyskusja. Jak dotąd skuteczność bewacyzumabu w leczeniu pierwszej linii u chorych na rozsianego raka piersi oceniono w trzech randomizowanych badaniach III fazy. We wszystkich tych badaniach stwierdzono znamienne wydłużenie PFS, bez istotnego zysku w zakresie OS. Na podstawie danych z literatury można przypuszczać, że konieczne jest wyodrębnienie podgrupy chorych, które odniosą największą korzyść z leczenia antyangiogennego. Aktualne doniesienia sugerują, ze najpewniej są to chore na potrójnie ujemnego raka piersi, które otrzymują bewacyzumab w skojarzeniu z chemioterapią w pierwszej linii leczenia, podobnie jak opisana przez nas chora.
\end{abstract}

\section{Bevacizumab in the 1 st line treatment of triple negative metastatic breast cancer patient - case report and review of the literature}

Introduction. Angiogenesis and VEGF (vascular endothelial growth factor) overexpression play an important role in the growth and development of many kinds of cancers. The role of bevacizumab, humanised, anti-VEGF antibody, in treatment of patients with metastatic breast canser (MBC) is still an open question. The aim of this paper is to present a case report of the use of bevacizumab with chemotherapy in the first line treatment of triple negative MBC.

Case. We present the case of a 57-year-old woman with infiltrating ductal carcinoma of the right breast (pT1N0M0, TNBC). She underwent wide excision of the tumour with the excision of right axillary lymph nodes, adjuvant chemoterapy and radiotherapy. Four years later metastases in the left lung (two lesions) and mediastinum occured. For

\footnotetext{
${ }^{1}$ Klinika Onkologii Klinicznej

2Zakład Radiodiagnostyki i Diagnostyki Obrazowej

Centrum Onkologii — Instytut im. Marii Sklodowskiej-Curie, Oddział w Gliwicach
} 
this reason the patient started immunochemotherapy - paclitaxel and bevacizumab. She ended paclitaxel after nine cycles, and continued bevacizumab as a maintenance. We observed a marked decrease in size of the metatstatic lesions. No serious adverse events during treatment were noted. From October 2009 to September 2013 the patient received 70 doses of bevacizumab. In September 2013 the treatment was ended due to progression of the size of the lung metastases. No new site of metastases was noted. The patient was considered suitable for stereotactic radiosurgery.

Discussion. To date three randomised, multicenter studies, which evaluated effectiveness of adding bevacizumab to chemotherapy were performed. In all trials significant prolongation of progression-free survival (PFS) was observed but with no statistically significant influence on overall survival (OS). The toxicity of the combined treatment was higher. Many experts put a great emphasis on the need to discover a group of patients who will gain a significant benefit from antiangiogenic treatment. Reports in the literature indicate that probably the greatest benefit from adding bevacizumab to the chemotherapy is gained by women with triple-negative breast cancer, who receive bevacizumab as first-line treatment after cancer progression, as our patient described above

NOWOTWORY Journal of Oncology 2014; 64, 4: 321-326

Słowa kluczowe: rozsiany rak piersi, bewacyzumab, angiogeneza

Key words: metastatic breast cancer, bevacizumab, angiogenesis

\section{Wprowadzenie}

Pomimo postępu w leczeniu chorych na raka piersi mediana przeżycia w przypadku wystąpienia przerzutów wynosi 2-3 lata [1,2]. Angiogeneza, w tym nadekspresja czynnika wzrostu śródbłonka naczyniowego (vascular endothelial growth factor - VEGF), odgrywa istotną rolę w inicjowania rozwoju wielu typów nowotworów, również raka piersi [3, 4]. Nadekspresja VEGF rozważana jest jako negatywny czynnik prognostyczny w przypadku raka piersi w stadium rozsiewu [5-7]. Niektóre z podtypów VEGF mogą też odgrywać istotną rolę jako czynniki predykcyjne dla odpowiedzi na leki antyangiogenne. W ostatnim czasie, na podstawie analizy danych z badania ECOG 2100, wykazano, że amplifikacja VEGF-A jest związana z gorszymi wynikami leczenia chorych na rozsianego raka piersi [8]. Zależność ta była szczególnie wyraźna w przypadku nadekspresji HER2 oraz raków potrójnie ujemnych. Ta i podobne obserwacje przyczyniły się do poszukiwania leków, które blokują proces angiogenezy. Bewacyzumab jest ludzkim monoklonalnym przeciwciałem anty-VEGF $[8,9]$. Rola bewacyzumabu w leczeniu chorych na raka piersi w stadium rozsiewu pozostaje nierozstrzygnięta, głównie z uwagi na brak znamiennej poprawy czasu przeżycia całkowitego (overall survival — OS) po dołączeniu tego przeciwciała do chemioterapii [9-11]. Pomimo to wielu autorów podkreśla, iż należałoby zwrócić szczególną uwagę na dobór podgrupy chorych, które odniosą istotny zysk z leczenia antyangiogennego [11-13].

Potrójnie negatywny rak piersi (triple negative breast cancer - TNBC) jest podtypem niewykazującym ekspresji receptorów estrogenowych, progesteronowych oraz HER2 [14]. Stanowi on około 10-20\% przypadków inwazyjnych raków piersi. TNBC wiąże się z gorszym rokowaniem w porównaniu z innymi podtypami, a wyniki leczenia nie są silnie zależne od wyjściowego stopnia zaawansowania nowotworu [14-16].

Celem pracy jest prezentacja przypadku chorej na rozsianego raka piersi, u której jako pierwszą linię leczenia zastosowano bewacyzumab w skojarzeniu z chemioterapią, uzyskując dobry, długotrwały efekt terapeutyczny.

\section{Opis przypadku}

57-letnia chora zgłosiła się do Centrum Onkologii — Instytutu im. Marii Skłodowskiej-Curie w Gliwicach w czerwcu 2005 roku z powodu guza piersi prawej. Chora była leczona od wielu lat z powodu nadciśnienia tętniczego, które było dobrze kontrolowane. Wykonano biopsję gruboigłową zmiany w piersi prawej, w badaniu histopatologicznym rozpoznano inwazyjnego raka przewodowego. Stopień zaawansowania klinicznego oceniono jako T1NOMO (bez cech rozsiewu w badaniach obrazowych: USG jamy brzusznej i miednicy mniejszej, RTG klatki piersiowej, scyntygrafia kośćca). Wobec powyższego chorą zakwalifikowano do zabiegu operacyjnego. Dnia 14 października 2005 roku wykonano szerokie wycięcie guza piersi prawej z prawostronną limfadenektomią pachową. W badaniu histopatologicznym materiału pooperacyjnego potwierdzono obecność naciekającego raka przewodowego piersi prawej: ER(-), PR(-), HER2(-), pT1NOM0 (żaden ze znalezionych 20 węzłów chłonnych nie był zajęty). Chora otrzymała cztery cykle adiuwantowej chemioterapii według schematu AC oraz uzupełniającą radioterapię. Nastepnie pozostawała pod obserwacją.

W kwietniu 2009 roku stwierdzono podejrzane zmiany w badaniach RTG oraz TK klatki piersiowej. Wykonano bronchofiberoskopię, jednak nie uzyskano reprezentatywnego materiału. Z uwagi na istotną progresję wielkości zmian w kolejnych badaniach TK klatki piersiowej rozpozna- 


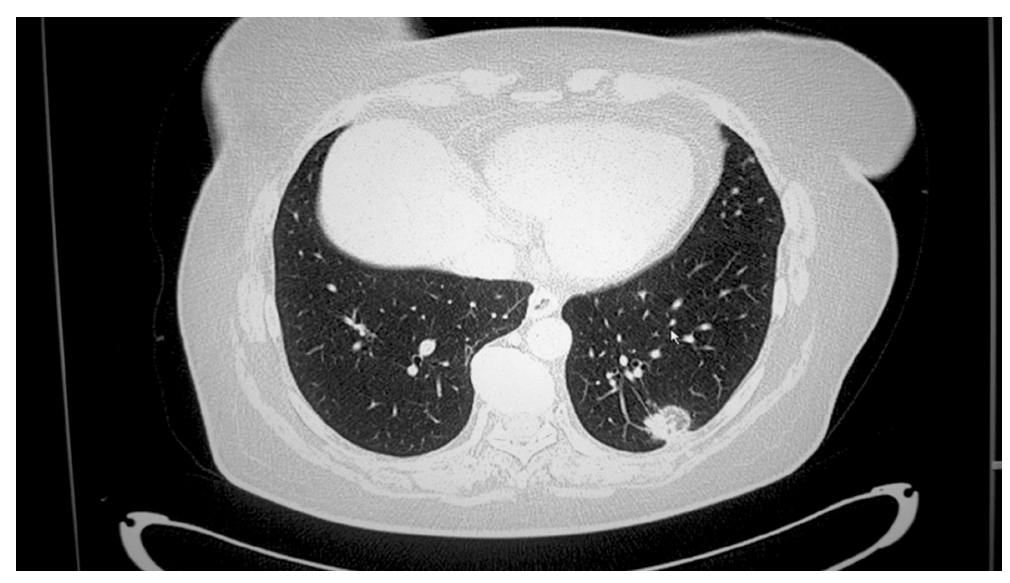

Rycina 1. Badanie TK klatki piersiowej wykonane dnia 24 sierpnia 2009 r.

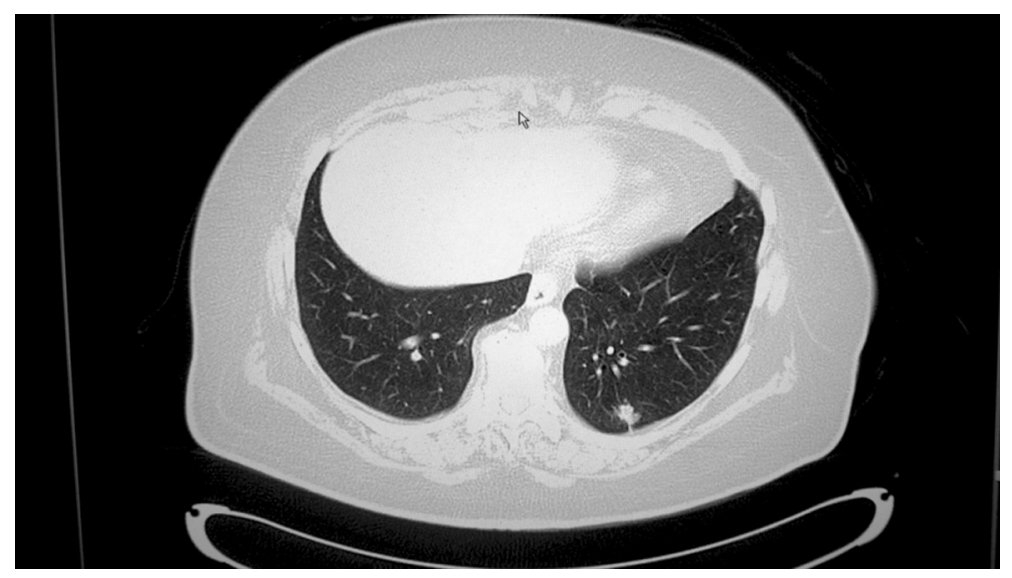

Rycina 2. Badanie TK klatki piersiowej wykonane dnia 21 grudnia 2009 r.

no rozsiew raka piersi do płuca lewego (dwie zmiany) oraz węzłów chłonnych śródpiersia (ryc. 1).

Chorą zakwalifikowano do immunochemioterapii: paklitaksel (80 mg/m², dzień 1, 8, 15; rytm 28 dni) z bewacyzumabem (10 mg/kg masy ciała, rytm $14 \mathrm{dni}$ ). Leczenie rozpoczęła dnia 26 października 2009 roku. Była to pierwsza linia leczenia po rozpoznaniu rozsiewu choroby. Od stycznia 2010 roku zredukowano dawkę paklitakselu o $20 \%$ z powodu nawracającej neutropenii G2. Chora otrzymała dziewięć cykli paklitakselu (do 28 czerwca 2010 roku), następnie kontynuowano podawanie bewacyzumabu w monoterapii (15 mg/kg masy ciała, rytm 21 dni). Po czterech cyklach immunochemioterapii stwierdzono zmniejszenie zmian przerzutowych o ponad $50 \%$. W kolejnych badaniach opisywano jedynie niewielkie zmiany resztkowe w płucu lewym (ryc. 2).

Tolerancja immunoterapii była dobra, nie obserwowano działań niepożądanych w stopniu 3. czy 4. Kontynuowano leczenie hipotensyjne bez konieczności modyfikacji dawek leków. Odnotowano kilka epizodów samoistnie ustępującego krwawienia z nosa. Ponadto po czwartej dawce bewacy- zumabu u chorej pojawiła się plamisto-grudkowa wysypka na twarzy. Konsultujący dermatolog rozpoznał trądzik różowaty i włączył adekwatne leczenie. Chora otrzymała łącznie 70 wlewów bewacyzumabu (do 30 września 2013 r., przy przyjęciu do ostatniego z wlewów nie był dostępny wynik badania TK). Od stycznia 2013 r. obserwowano powolne powiększanie się zmian w płucu lewym. WTK klatki piersiowej z września 2013 roku jednoznacznie rozpoznano progresję wielkości zmian w płucu lewym, węzły chłonne śródpiersia pozostały niepowiększone (ryc. 3).

Po wykluczeniu rozsiewu choroby do innych narządów chora została skierowana do Zakładu Radioterapii i zakwalifikowana do stereotaktycznego napromienienia zmian.

\section{Dyskusja}

Rola bewacyzumabu w leczeniu chorych na raka piersi w stadium rozsiewu pozostaje kontrowersyjna. Jak dotąd opublikowano trzy randomizowane badania III fazy, w których oceniano wyniki immunochemioterapii z bewacyzumabem $w$ leczeniu pierwszej linii u chorych na raka piersi 


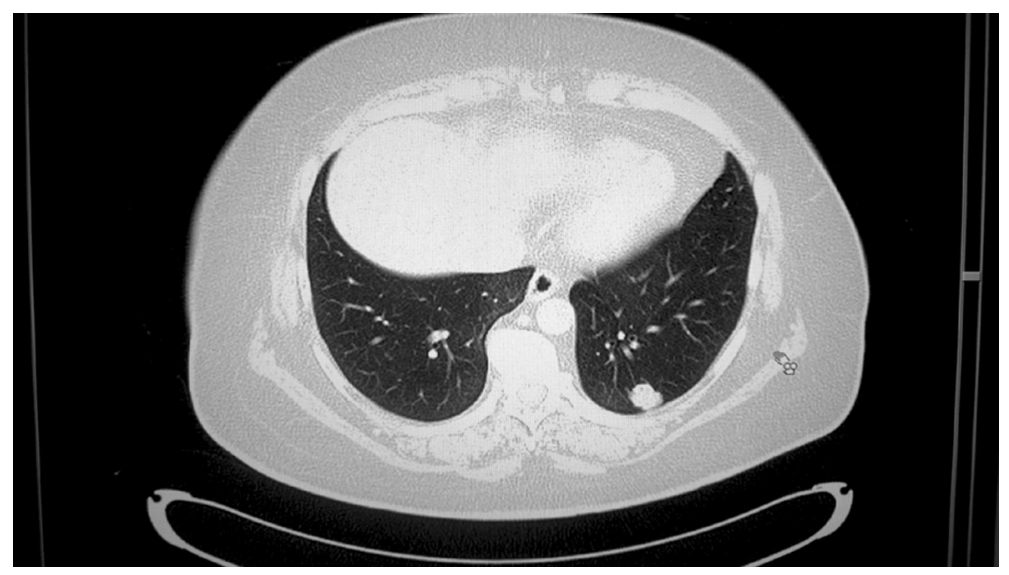

Rycina 3. Badanie TK klatki piersiowej wykonane dnia 26 września 2013 r.

w stadium rozsiewu. W badaniach tych wzięło udział łącznie 2646 kobiet. Leczenie kontynuowano do progresji bądź nieakceptowalnej toksyczności. We wszystkich badaniach pierwszorzędowym punktem końcowym był czas przeżycia wolnego od progresji (progression free survival - PFS).

W badaniu E2100 chore na rozsianego raka piersi były randomizowane do dwóch ramion; w jednym stosowano paklitaksel cotygodniowo $\left(80 \mathrm{mg} / \mathrm{m}^{2}\right)$, w drugim do chemioterapii dołączono bewacyzumab $(10 \mathrm{mg} / \mathrm{kg}$ masy ciała, rytm 14 dni) [10]. Mediana PFS uległa wydłużeniu po zastosowaniu bewacyzumabu: 11,8 vs 5,9 miesiąca ( $p<0,001)$. Zysk z zastosowania immunochemioterapii był niezależny od wieku chorej, stanu receptorowego, liczby i lokalizacji przerzutów, wielkości guza oraz wcześniej zastosowanego schematu adiuwantowej chemioterapii. Działania niepożądane w stopniu 3. lub 4., takie jak: nadciśnienie (14,8\%), białkomocz (3,6\%), bóle głowy (2,2\%), udar mózgu (1,9\%), infekcje (9,3\%), występowały częściej w grupie otrzymującej bewacyzumab. Nie obserwowano znamiennego zysku w zakresie czasu przeżycia całkowitego. Wyniki badania E2100 doprowadziły do zarekomendowania przez FDA (Food and Drug Administration) oraz EMA (European Medicines Agency) bewacyzumabu w skojarzeniu z paklitakselem w leczeniu pierwszej linii u chorych na rozsianego raka piesi.

W badniu AVADO chore były randomizowane do ramienia otrzymującego docetaksel ( $100 \mathrm{mg} / \mathrm{m}^{2}$, rytm $21 \mathrm{dni}$ ) lub docetaksel z bewacyzumabem (w dawce 7,5 lub $15 \mathrm{mg} / \mathrm{kg}$ masy ciała, rytm 21 dni) [17]. Po progresji dopuszczalne było cross-over. Pierwszorzędowy punkt końcowy, PFS, wyniósł odpowiednio 8,1 miesiąca w ramieniu samej chemioterapii, 9 miesięcy u chorych leczonych immunochemioterapią i 10,1 miesiąca w ramieniu, w którym podawano wyższą dawkę bewacyzumabu (p odpowiednio: 0,16 i 0,006).

Badanie RIBBON1 zostało zaprojektowane, aby ocenić skuteczność bewacyzumabu (15 mg/kg, rytm 21 dni) w skojarzeniu z różnymi cytostatykami - taksanami, antracyklinami oraz kapecytabiną [18]. Mediana PFS uległa wydłużeniu po dodaniu bewacyzumabu do każdego z tych cytostatyków. Podobnie jak w badaniu AVADO, zysk ten wyniósł około 1 miesiąca, a chorzy z ramion kontrolnych, po progresji, mogli otrzymać bewacyzumab jako leczenie drugiej linii. Toksyczność immunochemioterapii była istotnie wyższa niż samej chemioterapii.

W 2011 roku FDA wycofała rekomendację dla stosowania bewacyzumabu w leczeniu chorych na raka piersi w stadium rozsiewu. Decyzja ta była motywowana brakiem istotnego wydłużenia czasu przeżycia całkowitego po zastosowaniu immunochemioterapii przy znamiennie większej toksyczności leczenia oraz faktem, że zysk w zakresie PFS osiagnięty w badaniu E2100 nie był tak duży w kolejnych badaniach, pomimo że pozostawał statystycznie znamienny. EMA nie zgodziła się z decyzją FDA i podtrzymała stanowisko, że zastosowanie bewacyzumabu w pierwszej linii leczenia chorych na rozsianego raka piersi jest opcją terapeutyczną, jednak tylko w skojarzeniu z paklitakselem. Wielu badaczy kładzie nacisk na potrzebę wyodrębnienia podgrupy chorych, które odniosą największy zysk z leczenia antyangiogennego [13, 19-22]. Postuluje się, że wyraźnie większa toksyczność immunochemioterapii w badaniach AVADO i RIBBON1 może wynikać z faktu kojarzenia bewacyzumabu z cytostatykami innymi niż paklitaksel [23]. Traktowanie trzech omówionych badań jako równoważnych powinno odbywać się z dużą dozą ostrożności. Ponadto brak istotnego zysku w zakresie OS może hipotetycznie wynikać z faktu dostępności innych metod terapeutycznych zastosowanych po zakończeniu leczenia bewacyzumabem, powodujących wydłużenie przeżycia. Prowadzi to do „rozmycia" efektu terapeutycznego badanego leku [23]. Na podstawie dostępnych danych z literatury można zauważyć, że chore z niewielkimi zmianami przerzutowymi odnoszą największą korzyść z leczenia antyagiogennego $[24,25]$. W tych przypadkach ogniska martwicy w guzie są niewielkie lub nieobecne, a stymulacja dojrzewania patologicznych naczyń nowotworowych wydaje się mieć kluczowe znaczenie [24-27]. 
Doniesienia z literatury wskazują na to, że prawdopodobnie największy zysk z immunochemioterapii można uzyskać w przypadku rozpoznania TNBC i zastosowania bewacyzumabu w ramach leczenia pierwszej lini, jak w przypadku opisanej powyżej chorej [20, 28-30]. U chorych, które otrzymały wiele innych schematów chemioterapii przed włączeniem bewacyzumabu, uruchamiane są alternatywne szlaki angiogenezy, aktywowane np. za pośrednictwem FGF2 (fibroblastic growth factor), co czyni komórki nowotworowe opornymi na blokowanie działania VEGF $[29,30]$. Aktualnie toczą się badania nad wyodrębnieniem biomarkerów, które mogą być pomocne w przewidywaniu wrażliwości nowotworu na leczenie antyangiogenne. Takim markerem może być tzw.",gęstość sieci mikronaczyń" (microvessel density - MVD), oceniana metodami immunohistochemicznymi lub „przepuszczalność naczyń” (blood vessel leakness), oceniana z wykorzystaniem dekstranu znakowanego fluorescencyjnie [29, 31, 32]. Wiele prac dotyczy problemu krążących komórek śródbłonka (circulating endothelial cells - CECs) u chorych na raka piersi w stadium rozsiewu. Większa liczba CECs przed rozpoczęciem leczenia oraz w czasie jego trwania jest związana z długotrwałym efektem terapeutycznym [33, 34]. Również monitorowanie odpowiedzi nowotworu w czasie rzeczywistym oraz zmian jego ukrwienia może mieć istotne znaczenie. Metody obrazowania takie jak PET-TK, SPECT czy DCE-MRI są rozpatrywane jako narzędzia do oceny zaawansowania procesu angiogenezy w obrębie guza [35, 36]. Interesujacym jest także fakt, że samo stężenie VEGF w osoczu nie ma znaczenia prognostycznego [37].

W ostatnim czasie przeanalizowano dostępne próbki pobrane z tkanki nowotworowej u chorych, które brały udział w badaniu E2100 [8]. W analizie jednowariantowej stwierdzono, że w przypadku obu ramion amplifikacja genu VEGFA ma znaczenie prognostyczne. Wiąże się ona ze znamiennie gorszymi wynikami w odniesieniu do PFS i OS. Obserwacji tej nie potwierdzono jednak $w$ analizie wielowariantowej $(p=0,08)$. Autorzy podkreślili, że chore z rozpoznaniem TNBC lub raka HER2(+) i obecnością amplifikacji VEGFA osiągają znamiennie krótszy OS w porównaniu z chorymi na raka $\mathrm{ER}(+)$ lub PR(+), niezależnie od zastosowanego schematu leczenia. Ponadto u chorych leczonych bewacyzumabem amplifikacja VEGFA była związana z gorszymi wynikami w zakresie PFS i OS. Zależności takiej nie obserwowano u chorych w ramieniu kontrolnym.

W Klinice Onkologii Klinicznej Centrum Onkologii — Instytutu im. Marii Sklodowskiej-Curie w Gliwicach w okresie od lutego 2009 do września 2013 u dziewięciu chorych na rozsianego raka piersi zastosowano w pierwszej linii leczenia bewacyzumab w skojarzeniu z chemioterapią. Osiem chorych otrzymało bewacyzumab z paklitakselem, jedna — z kapecytabiną. Grupa ta jest oczywiście bardzo mała, jednak zwraca uwagę fakt, że we wszystkich przypadkach tolerancja leczenia była dobra, nie odnotowano poważnych zdarzeń niepożądanych. U jednej chorej obserwowano częściową regresję zmian przerzutowych w płucach i wątrobie, która trwała 17 miesięcy. Otrzymała ona immunochemioterapię - paklitaksel z bewacyzumabem, a następnie leczenie podtrzymujące bewacyzumabem. U kolejnych dwóch chorych obserwowano częściową regresję zmian przerzutowych, utrzymującą się odpowiednio przez 12 i 3 miesiące po zakończeniu immunochemioterapii (chore te nie otrzymały podtrzymującego leczenia bewacyzumabem). U pięciu chorych immunochemioterapię zakończono z powodu progresji choroby w trakcie leczenia. Opisana powyżej chora odniosła najdłuższy zysk z immunochemioterapii z następową podtrzymującą immunoterapią, przez 4 lata nie stwierdzono u niej progresji choroby, a toksyczność leczenia była akceptowalna.

Konflikt interesu: nie zgłoszono

\section{Dr Agnieszka Badora-Rybicka}

Klinika Onkologii Klinicznej

Centrum Onkologii — Instytut im. Marii Sklodowskiej-Curie

ul. Wybrzeże Armii Krajowej 15, 44-101 Gliwice

e-mail:agnieszka.k.badora@gmail.com

Otrzymano: 17 grudnia $2013 \mathrm{r}$.

Przyjęto do druku: 5 lutego $2014 \mathrm{r}$.

\section{Piśmiennictwo}

1. Pal SK, Gupta R, Somlo G i wsp. Lack of survival benefit in metastatic breast cancer with newer chemotherapy agents: The City of Hope cancer experience. J Clin Oncol 2008; 26: No 15 S (May Suppl), 2008: 1751020.

2. Gennari A, Conte P, Rosso R i wsp. Survival of metastatic breast carcinoma patients over a 20-year period: a retrospective analysis based on individual patient data from six consecutive studiem. Cancer 2005; 104: 1742-1750.

3. Ferrara N. Role of vascular endothelial growth factor in the regulation of angiogenesis. Kidney Int 1999; 56: 794-814.

4. Hicklin DJ, Ellis LM. Role of the vascular endothelial growth factor pathway in tumor growth and angiogenesis. J Clin Oncol 2005; 23: 1011-1027.

5. Foekens JA, Peters HA, Grebenchtchikov N i wsp. High tumor levels of vascular endothelial growth factor predict poor response to systemic therapy in advanced breast cancer. Cancer Res 2001; 61: 5407-5414.

6. Konecny GE, Meng YG, Untch Mi wsp. Association between HER-2/neu and vascular endothelial growth factor expression predicts clinical outcome in primary breast cancer patients. Clin Cancer Res 2004; 10: 1706-1716.

7. Sledge GW Jr. Vascular endothelial growth factor in breast cancer: biologic and therapeutic aspects. Semin Oncol 2002; 29 (3 Suppl 11): 104-110.

8. Schneider BP, Gray RJ, Radovich M i wsp. Prognostic and predictive value of tumor vascular endothelial growth factor gene amplifikation in metastatic breast cancer treated with paclitaxel with and without bevacizumab; results from ECOG 2100 trial. Clin Cancer Res 2013; 19: 1281-1289.

9. Presta LG, Chen $\mathrm{H}, \mathrm{O}^{\prime}$ Connor SJ i wsp. Humanization of an anti-vascular endothelial growth factor monoclonal antibody for the therapy of solid tumors and other disorders. Cancer Res 1997: 57: 4593-4599.

10. Miller K, Wang M, Gralow J i wsp. Paclitaxel plus bevacizumab versus paclitaxel alone for metastatic breast cancer. N Engl J Med 2007; 357: 2666-2676.

11. Carpenter D, Kesselheim AS, Joffe S. Reputation and precedent in the bevacizumab decision. N Eng J Med 2011; 365: e3.

12. D'Agostino RB Sr. Changing end points in breast-cancer drug approval - the avastin story. N Eng J Med 2011; 365: e2.

13. Goldfarb SB, Hudis C, Dickler MN. Bevacizumab in metastatic breast cancer: when may it be used? Ther Adv Med Oncol 2011; 3: 85-93. 
14. Cleere DW. Triple-negative breast cancer: a clinical update. Commun Oncol 2010; 7: 203-211.

15. Dent R, Trudeau M, Pritchard KI i wsp. Triple-negative breast cancer: clinical features and patterns of recurrence. Clin Cancer Res 2007; 13: 4429-4434.

16. Park YH, Lee SJ, Cho EY i wsp. Clinical relevance of TNM staging system according to breast cancer subtypes. Ann Oncol 2011; 22: 1554-1560.

17. Miles DW, Chan A, Dirix LY i wsp. Phase III study of bevacizumab plus docetaxel compared with placebo plus docetaxel for the first-line treatment of human epidermal growth factor receptor 2-negative metastatic breast cancer. J Clin Oncol 2010; 28: 3239-3247.

18. Robert NJ, Diéras V, Glaspy J i wsp. RIBBON-1: randomized, double-blind, placebo-controlled, phase III trial of chemotherapy with or without bevacizumab for first-line treatment of human epidermal growth factor receptor 2-negative, locally recurrent or metastatic breast cancer. J Clin Oncol 2011; 29: 1252-1260.

19. Dawood S, Shaikh AJ, BuchholzTA i wsp. The use of bevacizumab among women with metastatic breast cancer: a survey on clinical practice and the ongoing controversy. Cancer 2012; 118: 2780-2786.

20. Lord S, Harris AL. Angiogenesis - still a worthwhile target for breast cancer therapy? Breast Cancer Res 2010; 12 Suppl 4: S19.

21. Mackey JR, Kerbel RS, Gelmon KA i wsp. Controlling angiogenesis in breast cancer: a systematic review of anti-angiogenic trias. Cancer Treat Rev 2012; 38: 673-688.

22. Dienstmann R, Ades F, Saini KS i wsp. Benefit-risk assessment of bevacizumab in the treatment of breast cancer. Drug Saf 2012; 35: $15-25$

23. Di Leo $A$, Bleiberg $H$, Buyse $M$. Overall survival is not a realistic end point for clinical trials of new drugs in advanced solid tumors: a critical assessment based on recently reported phase III trials in colorectal and breast cancer. J Clin Oncol 2003; 21: 2045-2047.

24. Gerber HP, Ferrara N. Pharmacology and pharmacodynamics of bevacizumab as monotherapy or in combination with cytotoxic therapy in preclinical studies. Cancer Res 2005; 65: 671-680.

25. Jain RK. Normalizing tumor vasculature with anti-angiogenic therapy: a new paradigm for combination therapy. Nat Med 2001; 7: 987-989.

26. Rowe DH, Huang J, Kayton ML i wsp. Anti-VEGF antibody suppresses primary tumor growth and metastasis in an experimental model of Wilms' tumor. J Pediatr Surg 2000; 35: 30-32.

27. Barbastefano J, Garcia JA, Elson P i wsp. Association of percentage of tumour burden removed with debulking nephrectomy and progression-free survival in patients with metastatic renal cell carcinoma treated with vascular endothelial growth factor-targeted therapy. $B J U$ Int 2010; 106: 1266-1269.

28. Thomssen C, Pierga JY, Pritchard KI i wsp. First-line bevacizumab-containing therapy for triple-negative breast cancer: analysis of 585 patients treated in the ATHENA study. Oncology 2012; 82: 218-227.

29. Dirix LY, Van Dam PA, Prove AM i wsp. Bevacizumab in the treatment of patients with advanced breast cancer: where have we landed? Ther Adv Med Oncol 2010; 2: 331-342.

30. Relf M, LeJeune S, Scott PA i wsp. Expression of the angiogenic factors vascular endothelial cell growth factor, acidic and basic fi broblast growth factor, tumor growth factor beta-1, platelet-derived endothelial cell growth factor, placenta growth factor, and pleiotrophin in human primary breast cancer and its relation to angiogenesis. Cancer Res 1997; 57: 963-969.

31. Xian X, Hakansson J, Stahlberg A i wsp. Pericytes limit tumor cell metastasis. J Clin Invest 2006; 116: 642-651.

32. Wildiers $\mathrm{H}$, Guetens $\mathrm{G}$, De Boeck $\mathrm{G}$ i wsp. Effect of antivascular endothelial growth factor treatment on the intratumoral uptake of CPT-11. Br J Cancer 2003; 88: 1979-1986.

33. Calleri A, Bono A, Bagnardi V i wsp. Predictive potential of angiogenic growth factors and circulating endothelial cells in breast cancer patients receiving metronomic chemotherapy plus bevacizumab. Clin Cancer Res 2009; 15: 7652-7657.

34. Bidard FC, Mathiot C, Degeorges A i wsp. Clinical value of circulating endothelial cells and circulating tumor cells in metastatic breast cancer patients treated first line with bevacizumab and chemotherapy. Ann Oncol 2010; 21: 1765-1771.

35. Willmann JK, Kimura RH, Deshpande N i wsp. Targeted contrast-enhanced ultrasound imaging of tumor angiogenesis with contrast microbubbles conjugated to integrin-binding knottin peptides. $J \mathrm{NuCl}$ Med 2010; 51: 433-440.

36. O'Connor JP, Jackson A, Parker GJ i wsp. DCE-MRI biomarkers in the clinical evaluation of antiangiogenic and vascular disrupting agents. Br J Cancer 2007; 96: 189-195.

37. Schneider BP, Wang M, Radovich M i wsp. ECOG 2100; Association of vascular endothelial growth factor and vascular endothelial growth factor receptor-2 genetic polymorphisms with outcome in a trial of paclitaxel compared with paclitaxel plus bevacizumab in advanced breast cancer: ECOG 2100. J Clin Oncol 2008; 26: 4672-4678. 